\title{
Teen's Anxiety Through Poetry: Love or Dream?
}

\author{
Idha Nurhamidah \\ Fakultas Bahasa dan Ilmu Komunikasi \\ Universitas Islam Sultan Agung \\ idhanurhamidah@unissula.ac.id
}

\begin{abstract}
Teens are identical with instability and anxiety for which they need to express as their individual self-actualization. So far there have been no such efforts to accommodate their needs through literary works. The current study explores the dictions employed in English poems written by the students (identified as teens) of English Letters Study Program to find about how far a poem can be as a means for teens to express their feelings. The subjects were assigned to write poems of their interests. The 32 poems were then analyzed and interpreted to find out how most students expressed their anxieties in terms of love to parents, love to boy/girlfriends, friendship, hope, admiration, disappointment, encouragement, divinity and educational goals. The findings indicate that they turn out to be able to write poems when they are emotionally touched. In particular, they employed a limited range of lexical items to express their love to their parents, boy/girlfriends, in addition to love to their college in pursuit of their educational goals. As the general practice of teaching literature ending up with the students' analyzing literary works, it is high time that they were assigned to write poems to express their feelings.
\end{abstract}

Keywords: anxieties, poem, love, emotionally touched

\section{INTRODUCTION}

\section{Background}

It is arguably true that anxiety is an uncomfortable feeling. In this case, anxiety here, includes worry, confusion, uncertainty, sadness, disappointment, guilt, hesitation, etc (Ellis \& Dryden, 2007). If it is not immediately managed properly, and occurs over a long time and repeated, it can trigger other negative things such as: lack of enthusiasm, resulting in counterproductive, insecure, passive, pessimistic, self-blaming individuals (Wagner, 2002). They are so confined to the past that they cannot see the future. An individual who experiences anxiety requires a means to vent or dispense his or her anxiety. Whatever media is used to write does not dissolve the essence of a work since the value of a literary work is in individual words and how they are neatly arranged in such a way to attain the aesthetic value to be presented in poetic work without obscuring the meaning or purpose of creating literary works.

So far, the common practice of teaching literature - of which teaching poetry is one- has been kept or occupied by activities of the students' analyzing literary works, and reporting their final projects for end of semester examination or 
anything of the like (Perrine \& Arp, 1974). Very rarely (if any) do lecturers assign his or her students to produce literary works of their own interests, such as writing poems, plays or novels. The students' writing activities are limited to making responses to poems, novels or plays (Van, 2009). Isn't it high time that they were assigned to produce literary works? The current study is to focus on the students' products of literary works - poems written by the students in order to find out how they engineer dictions to accommodate their anxieties.

It has come to be known that, in literature, literary works divide into the works of fiction and non-fiction. Fictional works involves the author's element of subjectivity (Sapp \& Sapp, 1986), while non-fiction attempts to present the objective element of an event, an object or a person (Wiese, 2015). Included in the works of fiction are poetry, novels, memoirs, drama script, movie script, and others. While non-fiction works such as reports, articles, papers, theses, dissertations, and others. Heyne affirms the existence of factual elements or the right thing to happen in everyday life (Heyne, 1987). More, the language used is denotative and, therefore, leads to a limited understanding that does not mean double (Jackson, 2008). Poetry as one type of literary work of fiction, is the result of human thinking that is poured in words that are arranged in such a way that it contains deep meaning and high aesthetic value. The contents of the poem can be ideas or ideas, advice or messages, descriptions or arguments, and so on. Poetry can also be an expression of feeling for both positive and negative angles of look. Positive expressions or expressions may be flattery, admiration, support, or approval. Meanwhile, negative expressions may include criticism, disappointment, reproach, disagreement or resistance.

Furthermore, the process of poetry writing performed by an author is very dependent on the stock of knowledge he or she has. Irwanto (2016) discloses 'Four Ways of Knowing; namely through the senses, through imagination, through the heart or soul and through reason. It is through a poem that one can learn the psychological stance of the poet. The main objective of the current study is to investigate how diction representing anxiety in each individual poet (research subject) with respect to responding love, hope and other disruptive psychological breakdown is engineered or manipulated to achieve the goal.

\section{REVIEW OF RELATED THEORIES}

\section{Theme}

In an attempt to interpret the content, appreciate and / or analyze a poem, first of all an interpreter, appreciator, and analyst will find out the theme of the poem. Appropriate disclosure of themes will help in the interpretation and analysis process of interpretation. The theme is the main idea of something. According to Oxford Dictionary theme is the main idea; the basis of the story (which is spoken, used as the basis of composing, literary works) (Dictionary, 2008). Meanwhile, according to the dictionary of the term 'Popular Knowledge' the theme is the 
problem or the main idea that is described in an essay, the contents of a creation (Narvaez, Bentley, Gleason, \& Samuels, 1998). Likewise, the Encyclopedia of Indonesian Literature also defines the theme as any idea, main idea, or subject matter that is used as the basis of story-making.

The theme of a poem is therefore what it is all about. It can be about love, anger, dream, hope, etc. By looking at the theme, it is possible to anticipate what comes after what, including the structure of the poem. In short, when analyzing a poem, its theme must be identified first prior to investigating any other elements, leading to full comprehension of the poem to possibly learn the moral values.

\section{Teen and Anxiety}

The definition of adolescents by KBBI is adult; Have reached the age to marry ("KBBI," n.d.). Furthermore, according to WHO World Health Organization, which belongs to the category of teenage age is "those who are in the transition stage between childhood and adulthood; I.e. between the ages of 12 to 24 years" (WHO, n.d.). Tendency of adolescents to experience depression or stress disorder as an effect of physical and psychological transitions (Compas, 1987). It is argued that depression or stress in adolescents is due to the emergence of new expectations along with the intellectual development, including the manifestation of their inability of control, resulting in behavioral disorders

\section{Dictions}

The words chosen by the writer are known by the term 'diction', which according to Indonesian dictionary, is the right and harmonious word choice (in its use) to express the idea so as to obtain a certain effect (as expected) ("KBBI," n.d.). The element of 'word choice' in defining 'diction' which he thinks is very important in the world of fabricate and the world of speech (Jaddung, n.d.). According to him "diction is the choice of words. That is, we choose the right word to say something. The choice of the word must also fit the situation and place of use of the word. "Furthermore Jaddung suggests the use of the term in the dictionary to help find the right words.

\section{METHOD}

\section{A. Types of Research}

Used in this study literary works are interpretative to reveal the works of literature with the genre of poetry concerning the theme and diction (Kutha Ratna, 2008). The research subject are students participated in Poety class of 2016, while the object are the poems they composed

\section{B. Techniques for Data Collection and Analysis}

The data (Students' Poems) were collected by asking the students (subjects) to write poems to express their anxieties as expressions of self-actualization in free 
themes, maintaining the believed aesthetic values of poems within a period of no more than 90 minutes.

The collected poems were interpreted in terms of themes and classified according to theme classification theory (Khotimah, 2015). Each poem was reanalyzed to find out how anxieties were expressed in terms of choices of dictions (lexical items), adopting classification theory as used in Khotimah, 2015.

\section{FINDINGS AND DISCOUSSION}

The objects of this study are English poems compossed by students participating in Poetry Class; which according to the following figure are 32 titles of poetries_from Eva Irsyadah's Smile to Rafida Nur Azizah's Losing, from Muhammad Choirul Imam's You are My Life to Nur Masithah's Georgeous Lifes, from Siti Munawaroh's True Muslima to Fany Claudarista Mis Grumpy', from Siti Mar'atus Sholihah's My Best Friend to Kartika Celi's Mother Always There.

Students joins this class are in range of 19 to 21 who belong to teen. Teen are choosen as they DO face meticulous complex frustating problems in accordance to their lack of competence, experience and since about life against their expectation. Surely these make them get depressed; as can be observed from their poetries of anxiety as follow:

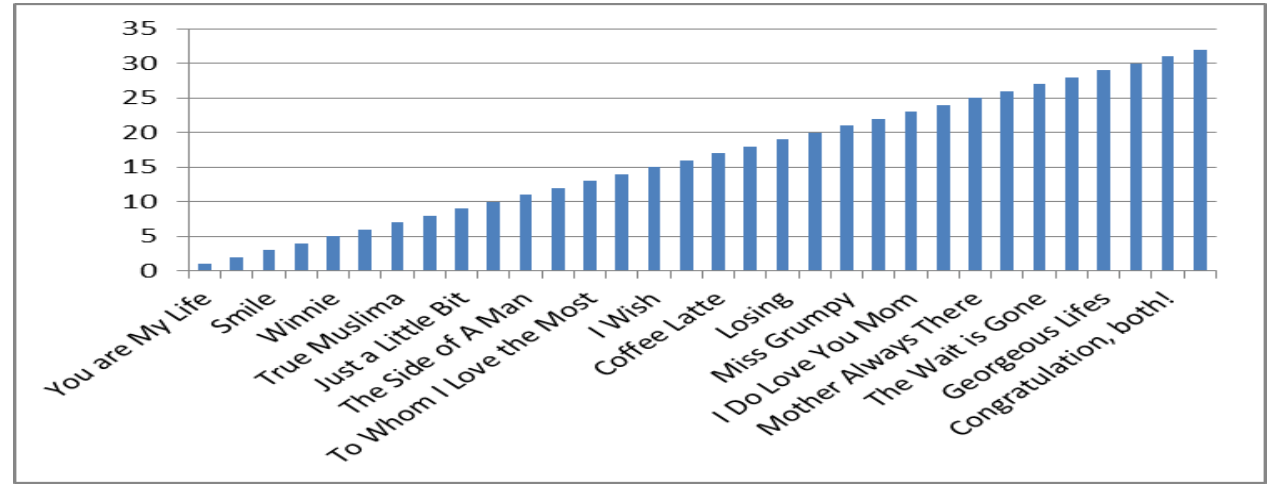

Picture 1. Poetries Titles

\section{Themes of the poetry}

The most themes are about love (41\%), hope (16\%), disappointment (13\%); many are about friendship and encouragement, both of them are 9\%; and few are about divinity (6\%), admiration and moving on (3\% each). Love becomes their most anxiety as teen who has been experiencing a switch from 'physicological needs' to 'love and belonging needs'. Had they biologically grow, they would have psychologically raised as well.

Just after the need of love and belonging had been fulfilled, they moved to need of self estem. This, among themes of the poetries are represented by 'hope' and 'disappointment. These three themes 'love, hope and disappoinment' which become very dominants are acknowledged as follow: 


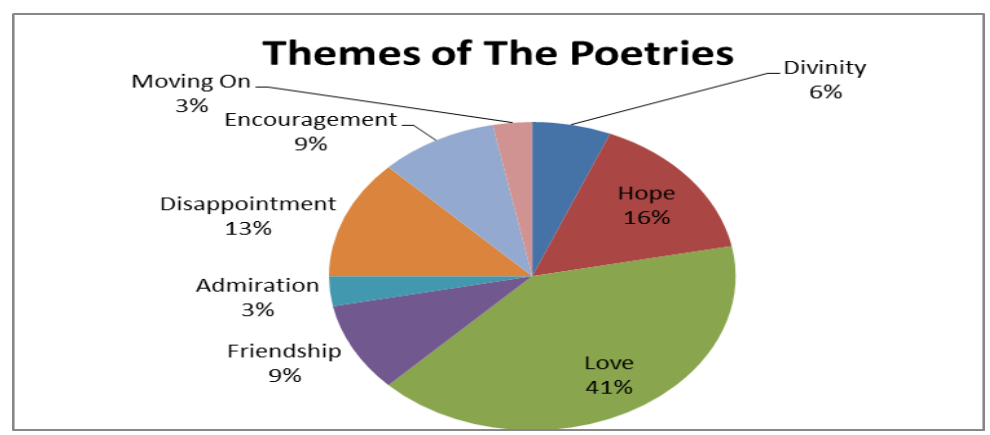

Picture 2. Themes of the Poetries

\section{Dictioning}

1. Love

Classified into this topic are Fergi Cintia Amaliah's The Side of A Man, Inok Tri Puji Rahayu's To Whom I Love the Most, Cici Nur Indah Sari's Rain Memories, Zulvida Nurani's I Wish, Siti Mar'atus Sholihah's My Best Friend, Nur Aisyah Jamil's Coffee Latte, Tika Rizkia Rahmawati's Always being You, Intan Ajeng Sebatian's I Do Love You Mom, Dwi Maftukhah's All I Want, Kartika Celi's Mother Always There, Syahrbanu Al Atas' Congratulation, both! And Tri Ilya Fajarwati's Mam.

Fergi's affection to him can be easily learned from her "I always looked into you//You are stand there with stout". He, who "There is no fear in your eyes//You are a man with your little smile". She can see inside him through "I knew it was just a mask//I knew that he felt frustrated", as a matter of fact "You live between two option//Waiting in vain or move forward and//forget everything about her.

Cici figure out her lost into freezing "Lost in the dark evening breeze//Alone, quite, enjoy the wind and freeze. This is due to her memories "My heart is froze remember you//My brain is curst thinking of you//My injuries much more severe because of you//My mouths keep it locked talk about you//My tears have dried crying for you. She hopes the rain comes "Remove my anger, disappointed, memories, love and sadness for you". However, though she desires that the memories go "You have to know, no matter how much I hate you//Honestly, this poem is belong to you"

Inok, Intan Ajeng, Kartika Celi and Tri Ilya have the same idea in their poem, conveying their love to their family members either to their father or their mother. Inok who just realized about how his father loves her much, tries to acknowledge about her ignorance to her father during this time "The biggest love he has to $\mathrm{me} /$ /Not his fault about his way//But me, about my ignorance", that through her poem, her love to her father is shown up by the line "You have to know, no matter how much I hate you//Honestly, this poem is belong to you".

Intan Ajeng as well as Kartika Celi and Tri Ilya, show how much they love their mother as in Intan Ajeng's I Do Love You Mom, she shows her love and thank to her mother for all the things her mother has done to her "You support me when I am down//You can tell me when I have problems//You are always there to accompany me... Thank you Mom".

2. Hope and disappointment 
Poetries 'If' by Andra Fakhrian expresses 'hope', so does Lia Endang Suryani's My Wish, Eva Irsyadah's Smile, and Putri Solekhah's Dream. Meanwhile, Defika Yuwirrandini's Done and Siti Nur Azizah D.H's The Wait is Gone express 'hopeless'. More Aisyah Wulandari's Tired, Rafida Nur Azizah's Losing Fany Claudarista's Miss Grumpy, Fitri Wijayanti's Hurt express 'disappointment'

Andra longing for someday "If, and if, and what if?//If someday, how?". He is in deep longing "Like yelling from a deep sorrow//Hopeless, hopelessly trapped within", more "Like a crying baby in anxiety hollow//Crawl on hands and knees, mumbling//Till birds stop singing, and I am begging//...//ff loophole is likely never//Never better be a zombie walking//And I am empty//.../Like a snow flake, falling, and gone//Even birds disgust me, and crush me//You are stink, your soul is stink". He DOES hope "Lord, oh Lord...//Please cure me...//Help me...//Bless me..." without clearly stating 'hope what, cure what, help him to what or bless him of what'

Meanwhile Eva manipulate her longing for hope into 'smile' indicates happiness "Smile...//Where were you//I miss the old you//Smile...//Reach $\mathrm{me} / / \mathrm{Hug} \mathrm{me} / / \mathrm{Let}$ us live again". And she promises "Smile...//I'll keep you//I'll protect you//Nobody can touch you//Smile...//This is my word//Trust me.

Contrast to Andra and Eva, Lia's hope of future is to remove the bad past events/memories "I closed my eyes//Slowly for awhile//I want to remove all of this things for a moment//I feel tired to carry this alone//I feel afraid to face the reality of life". Only "If I could turn back this time//I want to change everything", but she can't. Then, "I do not want to carry this burden in the future//I do not want to regret my past//I want to make anything beautiful in the future", after all.

\section{Friendship and Encouragement}

Topic of 'friendship' can be learn from poetries of Tika Ayu Rahmatika's Winnie, Siti Munawaroh's True Muslima, and Faradilla Mayanksari's Just a Little Bit. Almost in line with those poetries, Nazila Nahrotun Nahdian's Movement Enthusiasm, Nur Mashithoh's Georgeous Lifes, and Nurul Lailatu Suci's Yourself talk about 'encouragement'.

Tika named the friend 'Winnie', who is low, not superior. She is attentive, curious, and anthusias. Tika's words about her sound RIGHT with the assonance and consonance of 'ow' at once "Winnie how?//Winnie's low//Winnie should know//What now you know//Winnie won a bow//Without the arrow//Lost it in a row//Which never flow//Winnie's sick to show. Beside, employes beginning rhyme of 'w'.

Appreciating person of the same sex also done by Siti. The idolized person might be assumed better than her or she might want to be like her 'true muslima', who is believe in Allah "Moslem woman and believe in Allah//Good woman and keeping her dignity//She was afraid of sinning//Because the terrible hell". The hymne is "True muslima...//True muslima is faithful to Allah//True muslima always keep her tongue//True muslima always keep her chastity//True muslima are good mothers to their children".

Meanwhile, Nazila get frienship and encouragement from a spirit of a male 
friend who is identically 'brave' and 'be positive'. Let us have a look to the way she describes him "By the light of sight//And every he talk about//Something catch a feeling to brave//To fight in every single day". He motivates while conveys good value "In all we moved by greed//If the worlds pain were spaces//And he said, "move it!//Because in every movement is blessing"//We would live in the immensity". She becomes stronger "Then, today I was born for the second//Ignore the downhearted, and desperate//To face the real life come true//For the rainbow after the storm".

4. Divinity, Admiration and Moving on

Another positif senses can be observed from anxieties found in Mohammad Choirul Imam's You are My Life, and Nofia Ulfa's Authority of Night about the sense of divinity, in Septiarini Makodamayanti's Trigger is 'an admiration'; while in Nurul Karimah's Shilly Shally is a spirit to 'move on'.

Mohammad places himself on a feeling of alone when he forgets his God 'Allah' "I feel alone//I feel so lonely//When I forget that Allah always with us//O Allah//You're the light that above//You're the reason I never give up//You're the love that I need//It's sure You more love me before I love You//You more know me before I know You//You are my life".

Nofia convey her feeling to the Rabb, the authority of Night, "I've close my eyes//Look up hands while ask the night to//interpret my heart//Without one or two witnesses//Pit to Rabb, my night's authority".

Other than that, in Nurul Karimah's Shilly Shally, the line of "Go along toward the 'last' stop bus" becomes the point of the movement, followed by the next line, "The breeze fills my head, I drop into the stop light//Think thoughtlessly.../My bus just arrived, I leave".

\section{Love or Dream?}

Themes found in poems made by students in range of 19 up to 21 years are various and different between one another which each of the poem was written based on the feeling or the anxiety of the writer. That feeling or anxiety later comes into various kinds of theme such as hope, divinity, love, friendship, admiration, etc. Love and hope become the theme that are mostly chose and used by students as the theme of their poem. However, above all, love becomes the most themes used and chosen by them. Even so, other than that love theme, those are actually cannot be separated from love and still, those eventually, are tipped on the love.

\section{CONCLUSION}

Teens as those who are immature are close to the anxiety as a comfortable feeling that requires a means to be distributed and expended to. Writing a poem becomes one of the ways for them in expressing their feelings. In a study examining college students in range of 19 up to 21 years old, students wrote and made a poem that had been examined it was different between one another. It is found that there are various themes such as hope, admiration, friendship, dream, divinity, etc., chosen by students as the theme of their poem. For every theme 
chosen by students in their poem, at last, love is found as the most themes chosen by the teen. Thus, the theme about hope, admiration, friendship divinity, etc., All of that is tipped on the theme about love. Love is found as the feeling most teenagers have as a form of expression of their anxiety they vent through poetry.

\section{REFERENCES}

Compas, B. E. (1987). Stress and life events during childhood and adolescence. Clinical Psychology Review, 7(3), 275-302.

Dictionary, O. E. (2008). Oxford english dictionary. Retrieved May, 30, 2008.

Ellis, A., \& Dryden, W. (2007). The practice of rational emotive behavior therapy. Springer publishing company.

Heyne, E. (1987). Toward a theory of literary nonfiction. Modern Fiction Studies, 33(3), 479-490.

Jackson, J. (2008). Language. Identity and Study Abroad,, London: Equinox.

Jaddung. (n.d.). Pengertian dan Contoh Diksi. Retrieved from http://jaddung.blogspot.com/2015/06/pengertian-dan-contoh-diksi.html

KBBI. (n.d.). Retrieved from http://kbbi.web.id/diksi

Khotimah, A. A. K. (2015). Analisis Struktural Pada Puisi “Kesabaran” Karya Chairil Anwar.

Kutha Ratna, N. (2008). Teori, Metode, dan Teknik Penelitian Sastra: dari Strukturalisme hingga Postrukturalisme Perspektif Wacana Naratif. Yogyakarta: Pustaka Pelajar.

Narvaez, D., Bentley, J., Gleason, T., \& Samuels, J. (1998). Moral theme comprehension in third graders, fifth graders, and college students. Reading Psychology: An International Quarterly, 19(2), 217-241.

Perrine, L., \& Arp, T. R. (1974). Literature: structure, sound, and sense. Harcourt Brace Jovanovich.

Sapp, G., \& Sapp, G. (1986). The levels of access: Subject approaches to fiction. $R Q, 488-497$.

Van, T. T. M. (2009). The relevance of literary analysis to teaching literature in the EFL classroom. In English Teaching Forum (Vol. 47, p. 2). ERIC.

Wagner, A. P. (2002). Worried no more: Help and hope for anxious children. Lighthouse Press.

WHO. (n.d.). Teens. Retrieved from eprints.uny.ac.id/8119/4/bab 5 -08520244018.pdf

Wiese, A. (2015). Telling What Is True: Truthiness and Fictional Truths in Hybrid (Non) Fiction. Prose Studies, 37(1), 66-82.

\section{Appendix}

\begin{tabular}{|l|l|l|l|l|}
\hline No & \multicolumn{1}{|c|}{ Name } & \multicolumn{1}{|c|}{ Title } & \multicolumn{1}{|c|}{ Theme } & \\
\hline 1. & $\begin{array}{l}\text { Mohammad Choirul } \\
\text { Imam }\end{array}$ & You are My Life & $\begin{array}{l}\text { Divinity/spiritual } \\
\text { poem }\end{array}$ & 1 \\
\hline 2. & Andra Fakhrian & If & hope & 2 \\
\hline
\end{tabular}




\begin{tabular}{|c|c|c|c|c|}
\hline 3. & Eva Irsyadah & Smile & love & 3 \\
\hline 4. & Nurul Karimah & Shilly Shally & Moving on & 8 \\
\hline 5. & Tika Ayu Rahmatika & Winnie & friendship & 4 \\
\hline 6. & $\begin{array}{l}\text { Nazila Nahrotun } \\
\text { Nahdian }\end{array}$ & Movement Enthusiasm & encouragement & 7 \\
\hline 7. & Siti Munawaroh & True Muslima & friendship & 4 \\
\hline 8. & Lia Endang Suryani & My Wish & hope & 2 \\
\hline 9. & Faradilla Mayanksari & Just a Little Bit & friendship & 4 \\
\hline 10. & $\begin{array}{l}\text { Septiarini } \\
\text { Makodamayanti }\end{array}$ & Trigger & admiration & 5 \\
\hline 11. & Fergi Cintia Amaliah & The Side of A Man & love & 3 \\
\hline 12. & Aisyah Wulandari & Tired & disappointment & 6 \\
\hline 13. & Inok Tri Puji Rahayu & $\begin{array}{l}\text { To Whom I Love the } \\
\text { Most }\end{array}$ & Family, love & 3 \\
\hline 14. & Cici Nur Indah Sari & Rain Memories & love & 3 \\
\hline 15. & Zulvida Nurani & I Wish & love & 3 \\
\hline 16. & Siti Mar'atus S & My Best Friend & love & 3 \\
\hline 17. & Nur Aisyah Jamil & Coffee Latte & love & 3 \\
\hline 18. & Tika Rizkia Rahmawati & Always being You & love & 3 \\
\hline 19. & Rafida Nur Azizah & Losing & disappointment & 6 \\
\hline 20. & Putri Solekhah & Dream & Hope & 2 \\
\hline 21. & Fany Claudarista & Miss Grumpy & disappointment & 6 \\
\hline 22. & Fitri Wijayanti & Hurt & disappointment & 6 \\
\hline 23. & Intan Ajeng Sebatian & I Do Love You Mom & Family, love & 3 \\
\hline 24. & Dwi Maftukhah & All I Want & Love & 3 \\
\hline 25. & Kartika Celi & Mother Always There & Family, love & 3 \\
\hline 26. & Defika Yuwirrandini & Done & Hopelessness & 2 \\
\hline 27. & Siti Nur Azizah D.H & The Wait is Gone & Hopelessness & 2 \\
\hline 28. & Nofia Ulfa & Authority of Night & Divinity & 1 \\
\hline 29. & Nur Mashithoh & Georgeous Lifes & Encouragement & 7 \\
\hline 30. & Nurul Lailatu Suci & Yourself & Encouragement & 7 \\
\hline 31. & Syahrbanu & Congratulation, both! & Marriage, love & 3 \\
\hline 32. & Tri Ilya Fajarwati & Mam & Family, love & 3 \\
\hline
\end{tabular}

